\title{
Chirality Control in Crystalline Ni(II) Complexes of Thiophosphorylated Thioureas
}

\author{
Olga Kataeva ${ }^{1, *}$, Kirill Metlushka ${ }^{1}$, Zilya Yamaleeva ${ }^{1}$, Kamil Ivshin ${ }^{1,2}$, Ruzal Zinnatullin ${ }^{1}$, \\ Kristina Nikitina ${ }^{1}$, Dilyara Sadkova ${ }^{1}$, Elena Badeeva ${ }^{1}$, Oleg Sinyashin ${ }^{1}$ and \\ Vladimir Alfonsov ${ }^{1}$ \\ 1 Arbuzov Institute of Organic and Physical Chemistry, FRC Kazan Scientific Center, Russian Academy of \\ Sciences, Arbuzov str. 8, 420088 Kazan, Russia; metlushka@mail.ru (K.M.); zika0527@mail.ru (Z.Y.); \\ kamil.ivshin@yandex.ru (K.I.); zruza194@mail.ru (R.Z.); kristina-nik-25@mail.ru (K.N.); \\ Dilyara-Sadkova@yandex.ru (D.S.); ybadeev.61@mail.ru (E.B.); oleg@iopc.ru (O.S.); \\ alfonsov@yandex.ru (V.A.) \\ 2 A.M. Butlerov Chemistry Institute, Kazan Federal University, Kremlevskaya street 18, \\ 420008 Kazan, Russia \\ * Correspondence: olga-kataeva@yandex.ru
}

Received: 29 October 2019; Accepted: 19 November 2019; Published: 20 November 2019

\begin{abstract}
Chirality control over the formation of $\mathrm{Ni}$ (II) complexes with chiral thiophosphorylated thioureas was achieved via breaking the symmetry of nickel coordination geometry by the introduction of the pyridine ligand, while centrosymmetric meso-complexes are formed from racemic ligands in case of square-planar nickel coordination. Centrosymmetric heterochiral arrangement is observed in crystals of ligands themselves through $\mathrm{N}-\mathrm{H} \cdots \mathrm{S}$ hydrogen bonds in intermolecular dimers. Molecular homochirality in tetragonal pyramidal complexes is further transferred to supramolecular homochiral arrangement via key-lock steric interactions.
\end{abstract}

Keywords: chiral thiophosphorylated thioureas; chirality control; nickel(II) complexes; X-ray single crystal diffraction

\section{Introduction}

The comparison of intermolecular interactions in the crystals of enantiopure and racemic compounds is of primary importance to address the questions of chiral recognition, interplay between molecular and supramolecular chirality, bioactivity of chiral drugs, self-sorting and finally, the origin of homochirality [1-7]. Chiral recognition or preferential interactions between the enantiomers of the same chirality is difficult to achieve for conformationally flexible molecules, which possess multiple functional groups able to participate in a variety of molecular interactions. This might include hydrogen bonding, $\pi$-stacking, steric interactions, metal coordination, etc. At the same time, multiple possible intermolecular interactions upon certain conditions may provide not only discreet homochiral species, but chiral recognition on different levels: molecular level, formation of homochiral 1D-supramolecular chains, 2D-homochiral nets and finally, chiral resolution of racemic species. The strength and the directionality of molecular interactions leading to stable rigid supramolecular aggregates is the decisive factor for chiral recognition [8], e.g., the formation of centrosymmetric hydrogen-bonded dimers of chiral carbonic acids is the prevailing supramolecular synthon composed of enantiomers of opposite chirality $[9,10]$. This strong interaction prevents the formation of homochiral supramolecular species. 
Strange enough, metal coordination is rarely used to achieve chiral recognition, though coordination bonds are comparatively strong and directional. Recently [11,12], we have demonstrated chiral recognition in the crystals of $\mathrm{Ni}$ (II) complexes with chiral 1-(1-phenyl)ethyl3-(O,O-diethylthiophosphoryl)thioureas on different levels, including the formation of homochiral complexes and conglomerate crystals. Chiral thiophosphorylated thioureas are ideal compounds to study the processes of chiral recognition. They possess several hydrogen bond acceptors and donors, are able to coordinate metal ions, have conformationally flexible terminal groups that provide multiple modes of crystal packing depending on the crystal growth conditions. More important, one can introduce a variety of chiral auxiliaries of different volume and topology.

Herewith, we present the data on new chiral thiophosphorylated thioureas and their nickel(II) complexes in racemic and enantiopure form, addressing the stereochemical aspects of the molecular and supramolecular arrangement.

\section{Materials and Methods}

\subsection{Chemistry}

\subsubsection{General}

${ }^{1} \mathrm{H}$ NMR spectra were recorded on an AVANCE-400 (Bruker, Karlsruhe, Germany) instrument with the working frequency of $399.93 \mathrm{MHz}$ relative to the signals of residual protons of deuterated solvents $\left(\mathrm{CDCl}_{3}, \mathrm{C}_{6} \mathrm{D}_{6}\right),{ }^{31} \mathrm{P}$ NMR spectra were obtained on an AVANCE-400 (Bruker, Karlsruhe, Germany) instrument with the working frequency of $161.90 \mathrm{MHz}$ relative to the external standard $(85 \%$ $\mathrm{H}_{3} \mathrm{PO}_{4}$ ). IR spectra have been registered using a Tensor 27 Fourier spectrometer (Bruker, Karlsruhe, Germany) in the $400-4000 \mathrm{~cm}^{-1}$ range (optical resolution $4 \mathrm{~cm}^{-1}$ ). The samples were prepared as $\mathrm{KBr}$ pellets. The ESI MS measurements were performed using an AmazonX ion trap mass spectrometer (Bruker, Karlsruhe, Germany) in positive mode in the mass range of 70-3000. The capillary voltage was $-3500 \mathrm{~V}$, nitrogen drying gas $-10 \mathrm{~L} \cdot \mathrm{min}^{-1}$, desolvation temperature $-250{ }^{\circ} \mathrm{C}$. The sample was dissolved in $\mathrm{MeCN}$ or DMF to a concentration of $10^{-6} \mathrm{~g} \cdot \mathrm{L}^{-1}$. Data processing was performed by DataAnalysis 4.0 SP4 software (Bruker, version 4.0, Karlsruhe, Germany). Optical rotations were determined on a Perkin Elmer (Model 341) polarimeter at $20^{\circ} \mathrm{C}$. Melting points were measured on a BOETIUS melting point microscope.

All chemicals were purchased from Sigma-Aldrich (Moscow, Russia) and used without further purification.

\subsubsection{Syntheses}

( \pm )-1-(1,2,3,4-Tetrahydronaphthalen-1-yl)-3-(O,O-diethyl thiophosphoryl)thiourea (( $)$-1): O,O-diethyl thiophosphoryl isothiocyanate $(1.9 \mathrm{~g} ; 9 \mathrm{mmol})$ in acetonitrile $(4 \mathrm{~mL})$ was added dropwise to the solution of 1,2,3,4-tetrahydro-1-naphthylamine $(1.32 \mathrm{~g} ; 9 \mathrm{mmol})$ in acetonitrile $(8 \mathrm{~mL})$ under stirring. Resulting mixture was stirred at r.t. for 1 day under argon. After that the solvent was evaporated and the obtained viscous oil was recrystallized from the mixture of cyclohexane and ethyl acetate (10:1). The resulting precipitate was filtered off, washed with a small amount of cyclohexane and dried in vacuo to give ( \pm )-1. Yield: $2.5 \mathrm{~g}(77.8 \%)$; m.p. 97-99 ${ }^{\circ} \mathrm{C}$; IR $(\mathrm{KBr}): v\left(\mathrm{~cm}^{-1}\right) 3234(\mathrm{NH})$, 1541, 1487 (NCS), 1017 (C-O-P), 614 (P=S); ${ }^{1} \mathrm{H}$ NMR (400 MHz, CDCl ${ }_{3}$ ): $\delta$ (ppm) 1.25, 1.32 (2t, $\left.{ }^{3} J_{\mathrm{HH}}=7.1 \mathrm{~Hz}, 6 \mathrm{H}, \underline{\mathrm{CH}}_{3} \mathrm{CH}_{2} \mathrm{OP}\right), 1.80-2.01\left(\mathrm{~m}, 3 \mathrm{H}, \mathrm{CH}_{2} \_\mathrm{THNaph}\right), 2.15-2.23$ (m, 1H, $\underline{\mathrm{C}}_{2}$ _THNaph), 2.76-2.91 (m, 2H, $\underline{\mathrm{H}}_{2}$ THNaph), 4.09-4.19 (m, 4H, CH $\left.{ }_{3} \underline{\mathrm{CH}}_{2} \mathrm{OP}\right), 5.64-5.69$ (m, 1H, $\left.\underline{\mathrm{C}}_{\mathrm{THNaph}}\right), 7.03$ (d, $\left.{ }^{2} J_{\mathrm{PH}}=12.0 \mathrm{~Hz}, 1 \mathrm{H}, \underline{\mathrm{N}} \underline{\mathrm{HP}}\right), 7.12-7.36\left(\mathrm{~m}, 4 \mathrm{H}, \underline{\mathrm{C}}_{\mathrm{THNaph}}\right), 7.90\left(\mathrm{~d},{ }^{3} J_{\mathrm{HH}}=7.8 \mathrm{~Hz}, 1 \mathrm{H}, \underline{\mathrm{N}} \underline{\mathrm{HC}}(\mathrm{S})\right) ;{ }^{31} \mathrm{P} \mathrm{NMR}$ $\left(400 \mathrm{MHz}, \mathrm{CDCl}_{3}\right): \delta_{\mathrm{P}}(\mathrm{ppm}) 55.97 ; \mathrm{ESI}^{+}-\mathrm{MS}\left(\mathrm{CH}_{3} \mathrm{CN}\right): \mathrm{m} / z 359.1[\mathrm{M}+\mathrm{H}]^{+}, 229.1\left[\mathrm{M}+2 \mathrm{H}-\left\{\mathrm{C}_{10} \mathrm{H}_{11}\right\}\right]^{+}$; Elemental analysis calcd (\%) for $\mathrm{C}_{15} \mathrm{H}_{23} \mathrm{~N}_{2} \mathrm{O}_{2} \mathrm{PS}_{2}$ : C 50.26, H 6.47, N 7.81, P 8.64, S 17.89; found (\%): C 50.34, H 6.54, N 7.71, P 8.41, S 17.60 . 
Single crystals, suitable for X-ray diffraction analysis, were obtained by slow evaporation of the mother liquor after precipitate filtration.

(R)-1-(1,2,3,4-Tetrahydronaphthalen-1-yl)-3-(O,O-diethyl thiophosphoryl)thiourea ((R)-1): preparation method is the same as for $( \pm)$-1 using $(R)-1,2,3,4$-tetrahydro-1-naphthylamine as the initial amine. Viscous oil after solvent evaporation was dissolved in the mixture of cyclohexane and hexane (20:1) and kept at $5{ }^{\circ} \mathrm{C}$ for one week. The resulting precipitate was filtered off, washed with a small amount of hexane and dried in vacuo to give (R)-1. Yield: $2.66 \mathrm{~g}(82.7 \%)$; m.p. $90-91{ }^{\circ} \mathrm{C}$; $[\alpha]_{D}^{20}=+37.1$ (c 1.0, $\left.\mathrm{CHCl}_{3}\right)$; IR (KBr): $v\left(\mathrm{~cm}^{-1}\right) 3235(\mathrm{NH}), 1544,1486$ (NCS), 1017 (C-O-P), 613 $(\mathrm{P}=\mathrm{S}) ;{ }^{1} \mathrm{H}$ NMR $\left(400 \mathrm{MHz}, \mathrm{CDCl}_{3}\right): \delta(\mathrm{ppm}) 1.25,1.32\left(2 \mathrm{t},{ }^{3} \mathrm{~J}_{\mathrm{HH}}=7.1 \mathrm{~Hz}, 6 \mathrm{H}, \mathrm{CH}_{3} \mathrm{CH}_{2} \mathrm{OP}\right), 1.80-2.00$

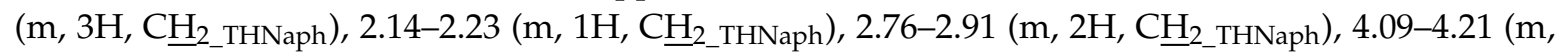
$\left.4 \mathrm{H}, \mathrm{CH}_{3} \underline{\mathrm{CH}}_{2} \mathrm{OP}\right), 5.64-5.69\left(\mathrm{~m}, 1 \mathrm{H}, \mathrm{C}_{\mathrm{THNaph}}\right), 7.03\left(\mathrm{~d},{ }^{2} J_{\mathrm{PH}}=11.9 \mathrm{~Hz}, 1 \mathrm{H}, \mathrm{NHP}\right), 7.12-7.36(\mathrm{~m}$, $\left.4 \mathrm{H}, \underline{\mathrm{C}}_{\mathrm{THNaph}}\right), 7.90\left(\mathrm{~d},{ }^{3} \mathrm{~J}_{\mathrm{HH}}=7.8 \mathrm{~Hz}, 1 \mathrm{H}, \mathrm{NHC}(\mathrm{S})\right) ;{ }^{31} \mathrm{P} \mathrm{NMR}\left(400 \mathrm{MHz}, \mathrm{CDCl}_{3}\right): \delta_{\mathrm{P}}(\mathrm{ppm}) 55.97$; $\mathrm{ESI}^{+}-\mathrm{MS}\left(\mathrm{CH}_{3} \mathrm{CN}\right): \mathrm{m} / z 359.1\left[\mathrm{M}+\mathrm{H}^{+}, 229.1\left[\mathrm{M}+2 \mathrm{H}-\left\{\mathrm{C}_{10} \mathrm{H}_{11}\right\}\right]^{+}\right.$; Elemental analysis calcd $(\%)$ for $\mathrm{C}_{15} \mathrm{H}_{23} \mathrm{~N}_{2} \mathrm{O}_{2} \mathrm{PS}_{2}$ : C 50.26, H 6.47, N 7.81, P 8.64, $\mathrm{S} 17.89$; found (\%): C 50.35, H 6.66, N 7.66, P 8.55, S 18.17 .

Single crystals, suitable for X-ray diffraction analysis, were obtained by slow evaporation of the mother liquor after precipitate filtration.

(S)-1-(1,2,3,4-Tetrahydronaphthalen-1-yl)-3-(O,O-diethyl thiophosphoryl)thiourea ((S)-1): preparation method is the same as for ( \pm )-1 using (S)-1,2,3,4-tetrahydro-1-naphthylamine as the initial amine. Thiourea $(S)-\mathbf{1}$ was isolated by the same crystallization procedure as for $(R)-\mathbf{1}$. Yield: $2.71 \mathrm{~g}(84.3 \%)$; m.p. $89-91^{\circ} \mathrm{C} ;[\alpha]_{D}^{20}=-36.8\left(\mathrm{c} 1.0, \mathrm{CHCl}_{3}\right)$; IR $(\mathrm{KBr}): v\left(\mathrm{~cm}^{-1}\right) 3235(\mathrm{NH}), 1543,1486$ (NCS), 1017 (C-O-P), 613 (P=S); ${ }^{1} \mathrm{H}$ NMR $\left(400 \mathrm{MHz}, \mathrm{CDCl}_{3}\right): \delta(\mathrm{ppm}) 1.25,1.32\left(2 \mathrm{t},{ }^{3} \mathrm{~J}_{\mathrm{HH}}=7.1 \mathrm{~Hz}\right.$, 6H, $\left.\underline{\mathrm{C}}_{3} \mathrm{CH}_{2} \mathrm{OP}\right), 1.81-2.01$ (m, 3H, $\underline{\mathrm{H}}_{2}$ THNaph), 2.14-2.23 (m, 1H, $\underline{\mathrm{C}}_{2}$ THNaph), 2.76-2.91 (m, 2H, $\left.\mathrm{C}_{2}{ }_{2} \mathrm{THNaph}\right), 4.08-4.19\left(\mathrm{~m}, 4 \mathrm{H}, \mathrm{CH}_{3} \underline{\mathrm{CH}}_{2} \mathrm{OP}\right), 5.64-5.69\left(\mathrm{~m}, 1 \mathrm{H}, \underline{\mathrm{C}}_{\mathrm{THNaph}}\right), 7.02\left(\mathrm{~d},{ }^{2} J_{\mathrm{PH}}=11.9 \mathrm{~Hz}\right.$, $1 \overline{\mathrm{H}}, \mathrm{N} \underline{\mathrm{HP}}), 7.12-7.36\left(\mathrm{~m}, 4 \mathrm{H}, \underline{\mathrm{C}}_{\mathrm{THNaph}}\right), 7.91\left(\mathrm{~d},{ }^{3} J_{\mathrm{HH}}=7.9 \mathrm{~Hz}, 1 \overline{\mathrm{H}}, \mathrm{NHC}(\mathrm{S})\right) ;{ }^{31} \mathrm{P}$ NMR $(400 \mathrm{MHz}$, $\left.\mathrm{CDCl}_{3}\right): \delta_{\mathrm{P}}(\mathrm{ppm}) 55.98 ; \mathrm{ESI}^{+}-\mathrm{MS}\left(\mathrm{CH}_{3} \mathrm{CN}\right): \mathrm{m} / z: 359.1[\mathrm{M}+\mathrm{H}]^{+}, 229.1\left[\mathrm{M}+2 \mathrm{H}-\left\{\mathrm{C}_{10} \mathrm{H}_{11}\right\}\right]^{+}$; Elemental analysis calcd (\%) for $\mathrm{C}_{15} \mathrm{H}_{23} \mathrm{~N}_{2} \mathrm{O}_{2} \mathrm{PS}_{2}$ : C 50.26, $\mathrm{H}$ 6.47, N 7.81, P 8.64, $\mathrm{S} 17.89$; found (\%): C 50.42, $\mathrm{H}$ $6.69, \mathrm{~N} 8.02$, P 8.43, S 17.69 .

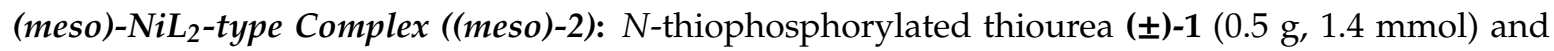
potassium hydroxide $(0.117 \mathrm{~g}, 2.1 \mathrm{mmol})$ were dissolved in methanol $(10 \mathrm{~mL})$. The resulting mixture was stirred during $10 \mathrm{~min}$, and after that a solution of $\mathrm{Ni}(\mathrm{II})$ chloride hexahydrate $(0.199 \mathrm{~g}, 0.84 \mathrm{mmol})$ in methanol $(5 \mathrm{~mL})$ was added to it. The reaction mixture was stirred at room temperature for a further $24 \mathrm{~h}$. After that, the solvent was evaporated, the resulting solid was dissolved in dichloromethane $(50 \mathrm{~mL})$ and extracted by water $(2 \times 15 \mathrm{~mL})$. The organic layer was separated and dried with anhydrous $\mathrm{Na}_{2} \mathrm{SO}_{4}$. Drying agent was filtered off, and the solvent was evaporated. The resulting solid was dissolved in the mixture of chloroform and hexane (3:5). During 2 weeks of slow evaporation of the mother liquor, crystals were formed, which were filtered off and dried in vacuo to give (meso)-2. Yield: 0.32 g (59.3\%); m.p. $186-187^{\circ} \mathrm{C}$; IR (KBr): $v\left(\mathrm{~cm}^{-1}\right) 3168$ (NH), 1562 (NCS), 1041, 1022 (C-O-P), 627 $(\mathrm{P}=\mathrm{S}) ;{ }^{1} \mathrm{H}$ NMR $\left(400 \mathrm{MHz}, \mathrm{C}_{6} \mathrm{D}_{6}\right): \delta(\mathrm{ppm}) 1.17,1.22\left(2 \mathrm{t},{ }^{3} \mathrm{~J}_{\mathrm{HH}}=6.9 \mathrm{~Hz}, 6 \mathrm{H}, \mathrm{CH}_{3} \mathrm{CH}_{2} \mathrm{OP}\right), 1.26-1.35$ (m, 1H, $\underline{\mathrm{H}}_{2}$ THNaph) $1.47-1.64$ (m, 2H, $\underline{\mathrm{H}}_{2}$ THNaph), $1.69-1.79$ (m, 1H, $\underline{\mathrm{H}}_{2}$ THNaph), 2.17-2.39 (m, $2 \mathrm{H}, \underline{\mathrm{C}}_{2}$ THNaph $), 3.89-4.22\left(\mathrm{~m}, 4 \mathrm{H}, \mathrm{CH}_{3} \underline{\mathrm{C}}_{2} \mathrm{OP}\right), 5.09-5.17$ (m, 1H, $\left.\underline{\mathrm{C}}_{\text {THNaph }}\right), 6.76-7.05(\mathrm{~m}, 3 \mathrm{H}$, $\left.\underline{\mathrm{CH}}_{\text {THNaph }}\right), 7.47-7.51\left(\mathrm{~m}, 1 \mathrm{H}, \underline{\mathrm{C}}_{\text {THNaph }}\right), 9.94$ (br.s, $\left.1 \mathrm{H}, \mathrm{NHC}(\mathrm{S})\right) ;{ }^{31} \mathrm{P} \mathrm{NMR}\left(400 \mathrm{MHz}, \mathrm{C}_{6} \mathrm{D}_{6}\right): \delta_{\mathrm{P}}$ (ppm) 58.13; ESI ${ }^{+}$-MS (DMF): $m / z 773.2[\mathrm{M}+\mathrm{H}]^{+}, 359.1[\mathrm{M}+2 \mathrm{H}-\mathrm{Ni}-\mathrm{L}]^{+}$; Elemental analysis calcd (\%) for $\mathrm{C}_{30} \mathrm{H}_{44} \mathrm{~N}_{4} \mathrm{NiO}_{4} \mathrm{P}_{2} \mathrm{~S}_{4}$ : C 46.58, H 5.73, N 7.24, Ni 7.59, P 8.01, S 16.58; found (\%): C 46.65, H 5.53, N 7.11, Ni 7.30, P 7.80, S 16.42. 
$(R, R)-N i L_{2}$-type Complex $((R, R)-2)$ : preparation method is the same as for (meso)-2 using $(R)-1$ as the initial thiourea. Recrystallization was carried out from the mixture of chloroform and hexane (2:5). During 2 weeks of slow evaporation of the mother liquor, crystals were formed, which were filtered off and dried in vacuo to give $(R, R)-2$. Yield: $0.28 \mathrm{~g}(51.9 \%)$; m.p. $136-138{ }^{\circ} \mathrm{C} ;[\alpha]_{D}^{20}=+245\left(\right.$ c $\left.0.3, \mathrm{C}_{6} \mathrm{H}_{6}\right)$; IR (KBr): $v\left(\mathrm{~cm}^{-1}\right) 3183(\mathrm{NH}), 1544$ (NCS), 1033, 1014 (C-O-P), 620 (P = S); ${ }^{1} \mathrm{H}$ NMR $\left(400 \mathrm{MHz}, \mathrm{C}_{6} \mathrm{D}_{6}\right)$ : $\delta(\mathrm{ppm}) 1.17,1.22\left(2 \mathrm{t},{ }^{3} \mathrm{~J}_{\mathrm{HH}}=7.0 \mathrm{~Hz}, 6 \mathrm{H}, \mathrm{CH}_{3} \mathrm{CH}_{2} \mathrm{OP}\right), 1.26-1.36\left(\mathrm{~m}, 1 \mathrm{H}, \mathrm{CH}_{2}\right.$ THNaph $), 1.46-1.65$ (m,

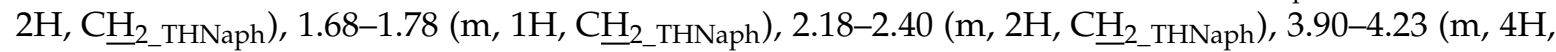
$\left.\mathrm{CH}_{3} \underline{\mathrm{C}}_{2} \mathrm{OP}\right), 5.10-5.16\left(\mathrm{~m}, 1 \mathrm{H}, \underline{\mathrm{C}}_{\mathrm{THNaph}}\right), 6.76-7.04$ (m, 3H, $\left.\underline{\mathrm{H}}_{\mathrm{THNaph}}\right), 7.48-7.51$ (m, 1H, $\left.\underline{\mathrm{H}}_{\mathrm{THNaph}}\right)$, 9.95 (br.s, $1 \mathrm{H}, \mathrm{N} \underline{\mathrm{HC}}(\mathrm{S})) ;{ }^{31} \mathrm{P} \mathrm{NMR}\left(400 \mathrm{MHz}, \mathrm{C}_{6} \mathrm{D}_{6}\right): \delta_{\mathrm{P}}$ (ppm) 58.40; $\mathrm{ESI}^{+}-\mathrm{MS}$ (DMF): $\mathrm{m} / z 773.2[\mathrm{M}+\mathrm{H}]^{+}$, $359.1[\mathrm{M}+2 \mathrm{H}-\mathrm{Ni}-\mathrm{L}]^{+}$; Elemental analysis calcd (\%) for $\mathrm{C}_{30} \mathrm{H}_{44} \mathrm{~N}_{4} \mathrm{NiO}_{4} \mathrm{P}_{2} \mathrm{~S}_{4}$ : C 46.58, H 5.73, N 7.24, Ni 7.59, P 8.01, S 16.58; found (\%): C 46.70, H 5.95, N 6.97, Ni 7.34, P 7.84, S 16.83.

$(S, S)-N i L_{2}$-type Complex $((S, S)-2)$ : preparation method is the same as for (meso)-2 using (S)-1 as the initial thiourea. Complex $(S, S)-2$ was isolated by the same crystallization procedure as for (R,R)-2. Yield: $0.29 \mathrm{~g}(53.7 \%) ;$ m.p. $135-137{ }^{\circ} \mathrm{C} ;[\alpha]_{D}^{20}=-243\left(\mathrm{c} 0.3, \mathrm{C}_{6} \mathrm{H}_{6}\right) ; \mathrm{IR}(\mathrm{KBr}): v\left(\mathrm{~cm}^{-1}\right) 3185$ (NH), 1544 (NCS), 1033, 1013 (C-O-P), $620(\mathrm{P}=\mathrm{S}) ;{ }^{1} \mathrm{H}$ NMR (400 MHz, $\left.\mathrm{C}_{6} \mathrm{D}_{6}\right): \delta(\mathrm{ppm})$ 1.17, $1.22(2 \mathrm{t}$, $\left.{ }^{3} \mathrm{~J}_{\mathrm{HH}}=7.0 \mathrm{~Hz}, 6 \mathrm{H}, \underline{\mathrm{CH}}_{3} \mathrm{CH}_{2} \mathrm{OP}\right), 1.26-1.36\left(\mathrm{~m}, 1 \mathrm{H}, \underline{\mathrm{C}}_{2}\right.$ THNaph $), 1.47-1.66\left(\mathrm{~m}, 2 \mathrm{H}, \mathrm{C}_{2} \underline{\mathrm{H}}_{2} \mathrm{THNaph}\right)$, 1.69-1.78 (m, 1H, $\underline{\mathrm{C}}_{2}$-THNaph), $2.18-2.40$ (m, 2H, $\underline{\mathrm{C}}_{2}$-THNaph), 3.88-4.22 (m, 4H, $\left.\mathrm{CH}_{3} \mathrm{C}_{2} \mathrm{OP}\right)$,

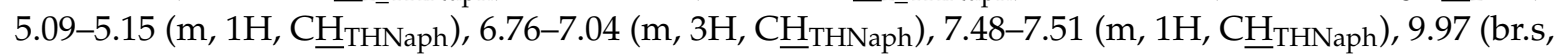
$1 \mathrm{H}, \mathrm{NHC}(\mathrm{S})) ;{ }^{31} \mathrm{P}$ NMR $\left(400 \mathrm{MHz}, \mathrm{C}_{6} \mathrm{D}_{6}\right.$ ): $\delta_{\mathrm{P}}$ (ppm) 58.43; ESI ${ }^{+}-\mathrm{MS}$ (DMF): $m / z 773.2[\mathrm{M}+\mathrm{H}]^{+}, 359.1$ $[\mathrm{M}+2 \mathrm{H}-\mathrm{Ni}-\mathrm{L}]^{+}$; Elemental analysis calcd (\%) for $\mathrm{C}_{30} \mathrm{H}_{44} \mathrm{~N}_{4} \mathrm{NiO}_{4} \mathrm{P}_{2} \mathrm{~S}_{4}$ : C 46.58, H 5.73, N 7.24, Ni 7.59, P 8.01, S 16.58; found (\%): C 46.81, H 5.93, N 7.04, Ni 7.42, P 8.04, S 16.79.

(rac)-NiL $L_{2} \cdot P y$-type Complex ((R,R/S,S)-3): $\mathrm{Ni}(\mathrm{II})$ acetate tetrahydrate $(0.138 \mathrm{~g}, 0.55 \mathrm{mmol})$ was dissolved in a mixture of pyridine $(0.176 \mathrm{~g}, 2.2 \mathrm{mmol})$ and methanol $(8 \mathrm{~mL}, 16 \mathrm{~mL}, 32 \mathrm{~mL})$. After that, the solution of racemic $N$-thiophosphorylated thiourea $( \pm)-1(0.4 \mathrm{~g}, 1.1 \mathrm{mmol})$ in methanol $(8 \mathrm{~mL}$, $16 \mathrm{~mL}, 32 \mathrm{~mL}$ ) was added dropwise, the resulting reaction mixture was shaken and left overnight at room temperature with slow evaporation of the solvent. The next day, a crystalline precipitate was formed. The flask with the reaction mixture was tightly closed and kept at room temperature for another 5 days. Thereafter, the precipitate was filtered off and dried in vacuo to give $(R, R / S, S)-3$. Yield: $0.37 \mathrm{~g}(77.8 \%)$ - at initial concentration of thiourea $( \pm)-1$ in a reaction mixture equal to $0.07 \mathrm{~mol} / \mathrm{L} ; 0.28 \mathrm{~g}$ $(58.8 \%)$-at initial concentration of thiourea $( \pm)-1$ in a reaction mixture equal to $0.035 \mathrm{~mol} / \mathrm{L} ; 0.22 \mathrm{~g}$ $(46.2 \%)$ - at initial concentration of thiourea $( \pm)-1$ in a reaction mixture equal to $0.0175 \mathrm{~mol} / \mathrm{L}$. In all cases, the same product was isolated. M.p. $176-178{ }^{\circ} \mathrm{C}$; IR (KBr): $\vee\left(\mathrm{cm}^{-1}\right) 3184(\mathrm{NH}), 1548$ (NCS), 1044, 1025 (C-O-P), 616 (P = S); ESI ${ }^{+}-\mathrm{MS}$ (DMF): $\mathrm{m} / \mathrm{z} 773.2[\mathrm{M}+\mathrm{H}]^{+}, 359.1[\mathrm{M}+2 \mathrm{H}-\mathrm{Ni}-\mathrm{L}]^{+}$; Elemental analysis calcd (\%) for $\mathrm{C}_{35} \mathrm{H}_{49} \mathrm{~N}_{5} \mathrm{NiO}_{4} \mathrm{P}_{2} \mathrm{~S}_{4}$ : C 49.30, $\mathrm{H} 5.79, \mathrm{~N}$ 8.21, Ni 6.88, P 7.26, S 15.04; found (\%): C 49.48, H 5.60, N 7.97, Ni 6.65, P 7.04, S 15.16.

$(R, R)-N_{i L} \cdot P y$-type Complex $((R, R)-3)$ : preparation method is the same as for $(R, R / S, S)-3$ using $(R)-1$ as initial thiourea (at initial concentration equal to $0.07 \mathrm{~mol} / \mathrm{L})$. Complex $(R, R)-3$ was isolated by the same crystallization procedure as for $(R, R / S, S)-3$. Yield: $0.31 \mathrm{~g}(65.2 \%) ; \mathrm{m} . p .145-147^{\circ} \mathrm{C}$; $[\alpha]_{D}^{20}=+180\left(\mathrm{c} 0.5, \mathrm{C}_{6} \mathrm{H}_{6}\right)$; IR (KBr): $v\left(\mathrm{~cm}^{-1}\right) 3181(\mathrm{NH}), 1549$ (NCS), 1047, 1026 (C-O-P), 615 $(\mathrm{P}=\mathrm{S}) ; \mathrm{ESI}^{+}-\mathrm{MS}$ (DMF): $\mathrm{m} / \mathrm{z} 773.2[\mathrm{M}+\mathrm{H}]^{+}, 359.1[\mathrm{M}+2 \mathrm{H}-\mathrm{Ni}-\mathrm{L}]^{+}$; Elemental analysis calcd $(\%)$ for $\mathrm{C}_{35} \mathrm{H}_{49} \mathrm{~N}_{5} \mathrm{NiO}_{4} \mathrm{P}_{2} \mathrm{~S}_{4}$ : C 49.30, H 5.79, $\mathrm{N}$ 8.21, Ni 6.88, P 7.26, S 15.04; found (\%): C 49.07, H 6.05, N 8.00, Ni 7.12, P 7.47, S 15.31. 
$(S, S)-N_{2} \cdot P y$-type Complex ((S,S)-3): preparation method is the same as for $(R, R / S, S)-3$ using $(S)-1$ as initial thiourea (at initial concentration equal to $0.07 \mathrm{~mol} / \mathrm{L})$. Complex $(S, S)-3$ was isolated by the same crystallization procedure as for $(R, R / S, S)-3$. Yield: $0.3 \mathrm{~g}(63.1 \%)$; m.p. $146-147{ }^{\circ} \mathrm{C}$; $[\alpha]_{D}^{20}=-181$ (c $\left.0.5, \mathrm{C}_{6} \mathrm{H}_{6}\right)$; IR (KBr): $v\left(\mathrm{~cm}^{-1}\right) 3178(\mathrm{NH}), 1549$ (NCS), 1046, 1026 (C-O-P), 614 $(\mathrm{P}=\mathrm{S}) ; \mathrm{ESI}^{+}-\mathrm{MS}$ (DMF): $\mathrm{m} / z$ 773.2 $[\mathrm{M}+\mathrm{H}]^{+}, 359.1[\mathrm{M}+2 \mathrm{H}-\mathrm{Ni}-\mathrm{L}]^{+}$; Elemental analysis calcd $(\%)$ for $\mathrm{C}_{35} \mathrm{H}_{49} \mathrm{~N}_{5} \mathrm{NiO}_{4} \mathrm{P}_{2} \mathrm{~S}_{4}$ : C 49.30, H 5.79, N 8.21, Ni 6.88, P 7.26, S 15.04; found (\%): C 49.22, H 5.55, N 8.01, Ni 7.16, P 7.50, S 15.06 .

\subsection{X-ray Diffraction Study}

Data sets for single crystals were collected on a Bruker AXS Kappa Apex diffractometer (Germany, Karlsruhe) with graphite-monochromated MoK $\alpha$ radiation $(\lambda=0.71073 \AA)$. The structures were solved by direct methods using APEX3 [13] for data collection, SAINT [14] for data reduction, SHELXS [15] for structure solution, SHELXL [15] for structure refinement by full-matrix least-squares against $\mathrm{F}^{2}$, and SADABS [16] for multi-scan absorption correction. Most of the crystals are of poor quality and exhibit positional disorder of the ethoxy-groups, which, for some crystals, was not possible to resolve, due to poor resolution. The corresponding fragments were refined isotropically. The poor quality of the crystals resulted in low accuracy of the geometrical parameters. Crystal $(R, R / S, S)-3$ contains $5 \%$ of acetate ion coordinated to nickel and $95 \%$ of pyridine, the evidence for the presence of acetate ion is provided by the presence of two peaks in the vicinity of pyridine and the non-positive definite nitrogen atom of the pyridine moiety. The data collection and refinement parameters are given in Table 1. CCDC 1961489-1961494 contains the supplementary crystallographic data for this paper (Supplementary Materials). 
Table 1. Crystallographic data and structure refinement details for compounds 1-3.

\begin{tabular}{|c|c|c|c|c|c|c|}
\hline Crystal & (R)-1 & $( \pm)-1$ & $(R, R)-2$ & (meso)-2 & $(R, R)-3$ & $(R, R / S, S)-3$ \\
\hline Formula & $\mathrm{C}_{15} \mathrm{H}_{23} \mathrm{~N}_{2} \mathrm{O}_{2} \mathrm{PS}_{2}$ & $\mathrm{C}_{15} \mathrm{H}_{23} \mathrm{~N}_{2} \mathrm{O}_{2} \mathrm{PS}_{2}$ & $\mathrm{C}_{30} \mathrm{H}_{44} \mathrm{~N}_{4} \mathrm{NiO}_{4} \mathrm{P}_{2} \mathrm{~S}_{4}$ & $\mathrm{C}_{26} \mathrm{H}_{40} \mathrm{~N}_{4} \mathrm{NiO}_{4} \mathrm{P}_{2} \mathrm{~S}_{4}$ & $\mathrm{C}_{35} \mathrm{H}_{49} \mathrm{~N}_{5} \mathrm{NiO}_{4} \mathrm{P}_{2} \mathrm{~S}_{4}$ & $\mathrm{C}_{35} \mathrm{H}_{49} \mathrm{~N}_{5} \mathrm{NiO}_{4} \mathrm{P}_{2} \mathrm{~S}_{4}$ \\
\hline CCDC number & 1961490 & 1961489 & 1961491 & 1961492 & 1961494 & 1961493 \\
\hline Color & colorless & colorless & violet & violet & Green & green \\
\hline Habitus & prizm & prizm & prizm & prizm & Prizm & prizm \\
\hline Size $(\mathrm{mm})$ & $0.69 \times 0.68 \times 0.39$ & $0.58 \times 0.38 \times 0.31$ & $0.56 \times 0.30 \times 0.19$ & $0.44 \times 0.31 \times 0.21$ & $0.52 \times 0.49 \times 0.26$ & $0.98 \times 0.39 \times 0.31$ \\
\hline Formula weight & 358.44 & 358.44 & 773.58 & 773.58 & 852.68 & 852.68 \\
\hline $\mathrm{T}(\mathrm{K})$ & $150(2)$ & $150(2)$ & $100(2)$ & $100(2)$ & $100(2)$ & $100(2)$ \\
\hline Crystal system & monoclinic & triclinic & monoclinic & monoclinic & monoclinic & orthorhombic \\
\hline Space group & $\mathrm{P} 2_{1}$ & $\mathrm{P}-1$ & $\mathrm{P} 2_{1}$ & $\mathrm{P} 2_{1} / \mathrm{c}$ & $\mathrm{P} 2_{1}$ & $\mathrm{Pna}_{1}$ \\
\hline$a(\AA)$ & $7.6020(10)$ & $7.5459(9)$ & $14.9354(6)$ & $19.4428(14)$ & $8.4467(11)$ & $23.6547(15)$ \\
\hline$b(\AA)$ & $30.256(4)$ & $8.1735(9)$ & $7.5352(3)$ & $12.3486(9)$ & $20.960(3)$ & $8.5751(5)$ \\
\hline$c(\AA)$ & $8.2300(11)$ & $15.2017(16)$ & $16.8715(7)$ & $15.5240(11)$ & $12.2036(17)$ & $20.0009(13)$ \\
\hline$\alpha\left({ }^{\circ}\right)$ & 90 & $92.278(6)$ & 90 & 90 & 90 & 90 \\
\hline$\beta\left({ }^{\circ}\right)$ & $108.423(5)$ & $90.123(6)$ & 112.192(2) & $104.448(4)$ & 107.971(6) & 90 \\
\hline$\gamma\left({ }^{\circ}\right)$ & 90 & 107.777(6) & 90 & 90 & 90 & 90 \\
\hline $\mathrm{V}\left(\AA^{3}\right)$ & $1795.9(4)$ & 892.01(17) & 1758.09(13) & $3609.3(5)$ & 2055.2(5) & $4057.0(4)$ \\
\hline $\mathrm{Z}$ & 4 & 2 & 2 & 4 & 2 & 4 \\
\hline D Calcd $\left(\mathrm{g} \mathrm{m}^{-3}\right)$ & 1.326 & 1.335 & 1.461 & 1.424 & 1.378 & 1.401 \\
\hline$\mu\left(\mathrm{mm}^{-1}\right)$ & 0.393 & 0.396 & 0.921 & 0.898 & 0.796 & 0.852 \\
\hline Reflection collected & 55072 & 5016 & 30788 & 89973 & 35088 & 65953 \\
\hline Unique reflections & 8927 & 5016 & 7769 & 8932 & 9905 & 9280 \\
\hline Reflections observed & 8899 & 4517 & 6896 & 4555 & 8455 & 8111 \\
\hline$\theta \min , \theta \max \left({ }^{\circ}\right)$ & $1.347,28.346$ & $1.341,28.390$ & $1.303,27.236$ & $1.081,28.378$ & $1.754,28.375$ & $1.722,27.541$ \\
\hline Goodness-of-fit (GOF) on F2 & 1.121 & 1.125 & 1.121 & 1.160 & 0.845 & 1.181 \\
\hline $\mathrm{R} 1, \mathrm{wR} 2(\mathrm{I} \geq 2 \sigma(\mathrm{I}))$ & $0.0228,0.0606$ & $0.0392,0.0952$ & $0.0446,0.1129$ & $0.1345,0.3012$ & $0.0423,0.1092$ & $0.0547,0.1540$ \\
\hline R1, wR2 (all data) & $0.0228,0.0607$ & $0.0454,0.0970$ & $0.0550,0.1325$ & $0.2452,0.3519$ & $0.0552,0.1297$ & $0.0643,0.1620$ \\
\hline Largest peak/hole $\left(\mathrm{e} \AA^{-3}\right)$ & $\begin{array}{c}0.296 \\
-0.248\end{array}$ & $\begin{array}{c}0.389 \\
-0.266\end{array}$ & $\begin{array}{c}1.321 \\
-0.943\end{array}$ & $\begin{array}{c}0.749 \\
-1.132\end{array}$ & $\begin{array}{c}0.539 \\
-0.859\end{array}$ & $\begin{array}{c}1.553 \\
-0.575\end{array}$ \\
\hline Flack & $0.007(6)$ & & $0.007(10)$ & & $0.013(17)$ & $0.397(8)$ \\
\hline
\end{tabular}




\section{Results and Discussion}

The racemic and enantiopure thiophosphorylated thioureas 1 were synthesized by the addition reaction of the corresponding 1,2,3,4-tetrahydro-1-naphthylamine with O,O-diethyl thiophosphoryl isothiocyanate (Scheme 1). Square-planar complexes 2 and tetragonal pyramidal complexes 3 were obtained by the reactions of $\mathbf{1}$ with nickel(II) salts in the presence of potassium hydroxide (Scheme 2) and pyridine (Scheme 3), respectively. The syntheses of complexes 3 were carried out in the excess of pyridine, thus, one could expect pyridine to occupy both axial positions, however, no octahedral complexes were formed. To prove the exclusive formation of homochiral complexes from $( \pm)-1$ in the presence of pyridine, the syntheses of $(R, R / S, S)-3$ were carried out using different initial concentrations of precursors. The same products were obtained independent of concentrations.

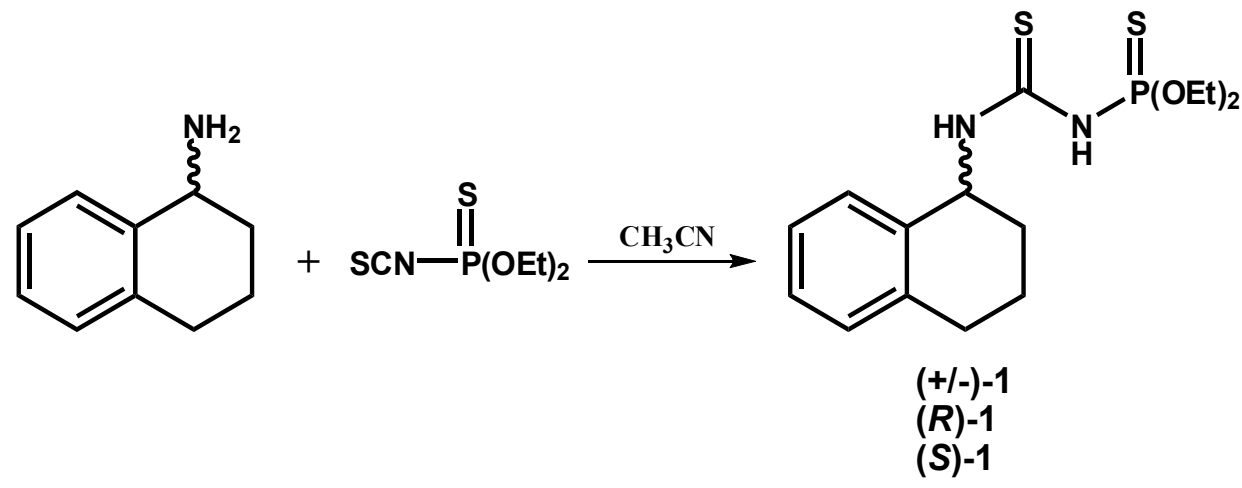

Scheme 1. The synthesis of N-thiophosphorylated thioureas 1.<smiles>CCO[P+](=S)NC(=S)N[C@H]1CCCc2ccccc21</smiles>

Scheme 2. The synthesis of square-planar complexes 2.<smiles>CCO[P+](=S)NC(=S)N[C@H]1CCCc2ccccc21</smiles>

Scheme 3. The synthesis of tetragonal pyramidal complexes 3.

Thiophosphorylated thioureas $\mathbf{1}$ are conformationally flexible compounds, which can adopt a variety of conformations very close on an energy scale [12]. Moreover, they exhibit nearly free internal rotation of the terminal ethoxy groups. In addition, they have several donor atoms able to coordinate metal ions, thereby they can display a variety of coordination modes in the complexes with transition 
metals, depending on the intramolecular interactions and the corresponding preferable conformations. As it was shown in a series of publications [17-25], the most abundant coordination mode of thiophosphorylated thioureas is 1,5-S,S metal coordination with the formation of the six-membered metal containing cyclic fragments, while the $1,3-N, S$ mode is rare $[12,20,24,26,27]$.

Compound 1 in racemic and enantiopure crystals have similar molecular structures with two $\mathrm{N}-\mathrm{H}$ bonds being trans to each other (Figure 1). Two sulfur atoms are also on opposite sides of the $\mathrm{N}-\mathrm{C}-\mathrm{N}-\mathrm{P}$ fragment. Such a molecular structure ideally complies with the geometry requirements of metal complexes with 1,3-N,S-coordination. In a racemic crystal, the molecules form nearly planar centrosymmetric dimers via the $\mathrm{N}-\mathrm{H} \cdots \mathrm{S}$ hydrogen bonding. This supramolecular synthon is very stable and is reproduced in enantiopure crystals through pseudocentrosymmetric arrangement of two crystallographically independent molecules (Figure 1).

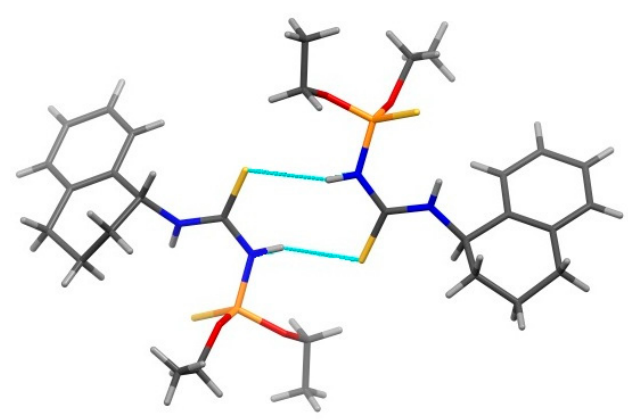

$(R)-1$

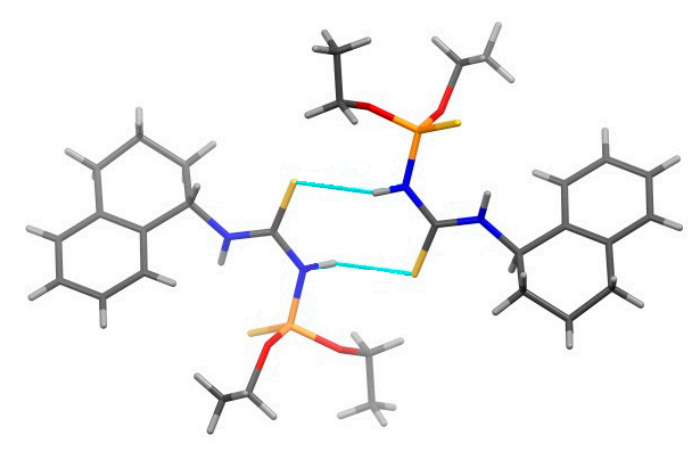

$( \pm)-1$

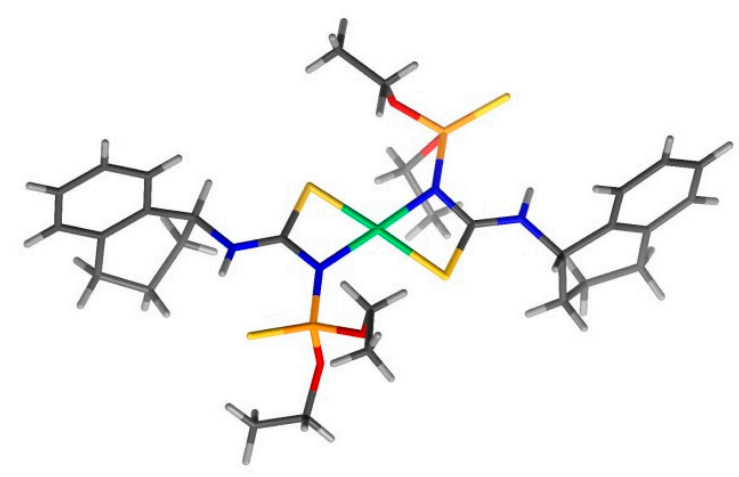

$(R, R)-2$

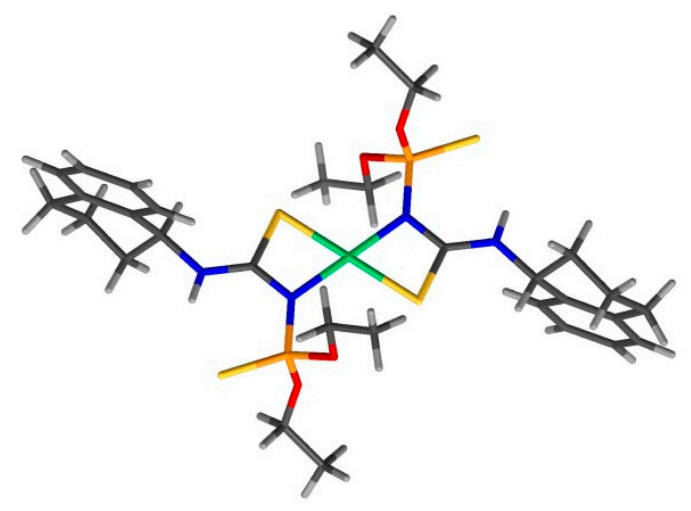

(meso)-2

Figure 1. Hydrogen bonded dimers of $\mathbf{1}$ and square-planar Ni(II) complexes $\mathbf{2}$ in enantiopure and racemic crystals.

Analyzing the geometry of hydrogen bonded dimers in the crystals of $\mathbf{1}$, one can see an ideal preorganization of the ligands for $1,3-\mathrm{N}, S$-coordination of nickel (II) ions. Indeed, the X-ray single diffraction study shows the formation of 2:1 square-planar complexes with 1,3-N,S-coordination (Figure 1). Most important is that heterochiral centrosymmetric meso-complexes are formed from racemic ligands owing to the centrosymmetric $\mathrm{Ni}(\mathrm{II})$ coordination geometry. Interaction of $(R)-1$ produced pseudocentrosymmetric homochiral complexes $(R, R)-2$. Worth mentioning is the transferability of the supramolecular geometry arrangement from dimeric hydrogen bonded synthon to the $\mathrm{Ni}$ (II) complex. One should note the equal distances between the donor atoms in dimers and in the complexes (Figure 1). The pseudocentrosymmetric planar arrangement of two molecules of $(\boldsymbol{R})-\mathbf{1}$ in homochiral dimers is quite distinct from the folded geometry of the dimers of the 1-phenylethyl-containing (R)-thiophosphorylated thioureas [12]. Interestingly, the crystallization 
of square-planar $\mathrm{Ni}$ (II) complexes of the latter yielded no single crystals that were suitable for X-ray diffraction analysis.

To break the symmetry of the $\mathrm{Ni}(\mathrm{II})$ coordination geometry, we have introduced an additional axial pyridine ligand (Scheme 3), which results in the exclusive formation of homochiral tetragonal pyramidal complexes from racemic ligands (Figure 2). Thus, the symmetry break via introduction of the axial ligand may be widely used to access homochiral complexes on a molecular level. Moreover, for racemic 3, homochirality was achieved on a supramolecular level. In both crystals of racemic 3 and $(R, R)-3$, supramolecular homochiral chains are formed owing to key-lock steric interactions with pyridine ligands located in the cavity at the base of coordination pyramid of the neighbouring complex. The $\mathrm{C}-\mathrm{H} \cdots \mathrm{Ni}$ contacts in crystals 3 are slightly longer (2.84-2.87 $\AA$ ) than in 1-phenylethyl-containing complexes [12]. The molecules in a supramolecular chain are related via a translation operation. In racemic 3, the supramolecular chains of opposite chirality interact via weak $\mathrm{C}-\mathrm{H} \cdots \mathrm{S}$ and $\mathrm{C}-\mathrm{H} \cdots \pi$ interactions. These types of short contacts are also revealed in other crystals, depending on the conformations of the terminal ethoxy groups, the latter adopt gauche and trans-conformations (Table 2), with the torsional angles varying in wide limits.
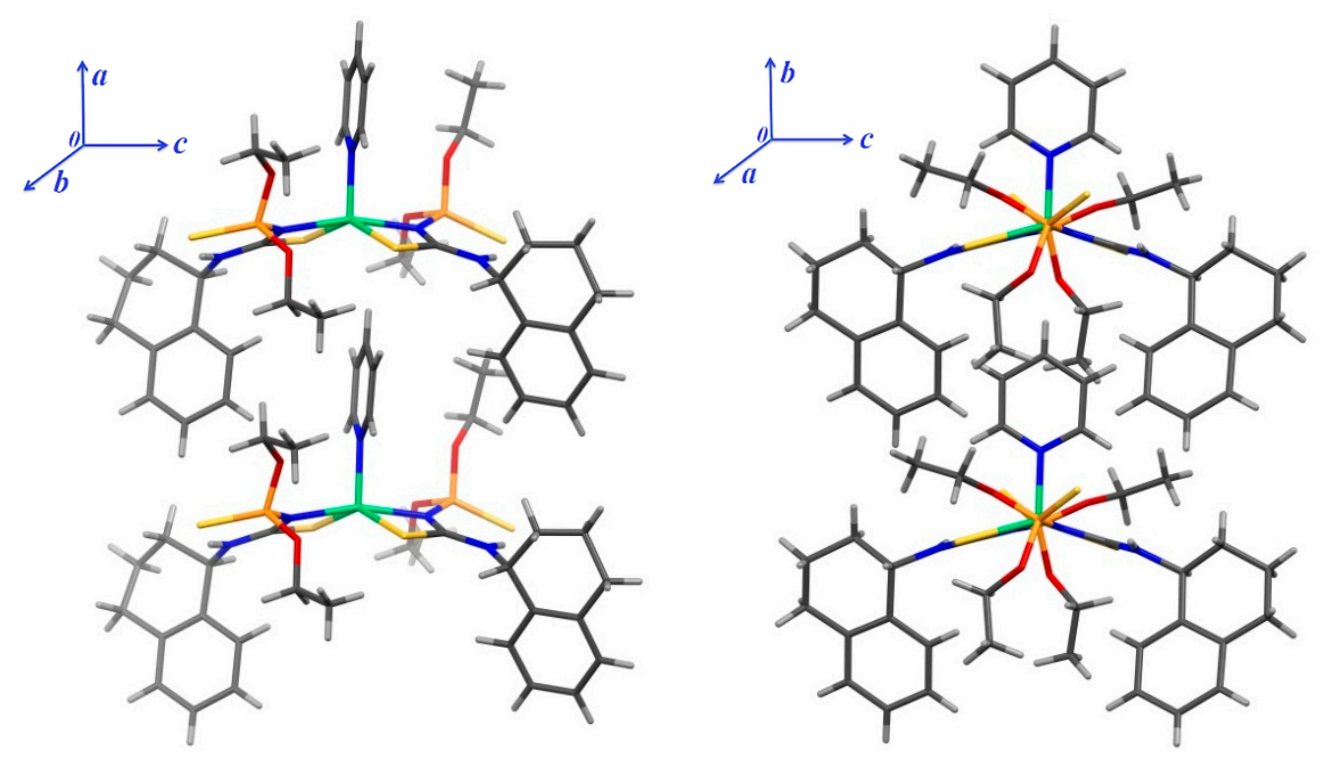

Figure 2. Molecular structure and the arrangement of molecules in homochiral supramolecu lar chains in the crystals of enantiopure $(R, R)-3$ (left) and racemic 3 (right).

To conclude, new chiral thiophosphorylated thioureas were synthesized in racemic and enantiopure form. In racemic crystals, the molecules form nearly planar centrosymmetric dimers via the $\mathrm{N}-\mathrm{H} \cdots \mathrm{S}$ hydrogen bonding. This supramolecular synthon is very stable and is reproduced in enantiopure crystals through pseudocentrosymmetric arrangement of two crystallographically independent molecules. The obtained thioureas exhibit the 1,3-N,S-coordination mode with $\mathrm{Ni}(\mathrm{II})$ and form 2:1 complexes. Meso-complexes are formed from racemic ligands with a centrosymmetric square-planar nickel coordination. Breaking the symmetry of nickel coordination geometry by the introduction of axial pyridine ligand results in homochiral complexes from racemic ligands. Molecular homochirality in tetragonal pyramidal complexes is further transferred to supramolecular homochiral arrangement via key-lock steric interactions. Thus, the presented approach allows to control the diastereoselectivity of complex formation without additional chiral auxiliaries. The key-lock homochiral supramolecular interactions show the perspective to obtain 1D-homochiral coordination polymers. Further studies on chirality control beyond the molecular level to achieve 3D supramolecular homochirality are in progress. 
Table 2. Selected torsion angles (deg.) in the ligands and complexes.

\begin{tabular}{|c|c|c|c|c|c|c|}
\hline Crystal & $\mathrm{S}=\mathrm{P}-\mathrm{N}-\mathrm{C}$ & $\begin{array}{l}\mathrm{S}=\mathrm{P}-\mathrm{O}-\mathrm{C} \\
\mathrm{P}-\mathrm{O}-\mathrm{C}-\mathrm{C}\end{array}$ & $\begin{array}{l}\mathrm{S}=\mathrm{P}-\mathrm{O}-\mathrm{C} \\
\mathrm{P}-\mathrm{O}-\mathrm{C}-\mathrm{C}\end{array}$ & $\begin{array}{l}\mathrm{S}=\mathrm{P}-\mathrm{O}-\mathrm{C} \\
\mathrm{P}-\mathrm{O}-\mathrm{C}-\mathrm{C}\end{array}$ & $\begin{array}{l}\mathrm{S}=\mathrm{P}-\mathrm{O}-\mathrm{C} \\
\mathrm{P}-\mathrm{O}-\mathrm{C}-\mathrm{C}\end{array}$ & $\begin{array}{l}\text { Pyridine } \\
\text { Orientation }\end{array}$ \\
\hline $\begin{array}{c}(\boldsymbol{R})-\mathbf{1} \\
(\mathrm{mol} \mathrm{A})\end{array}$ & $-56.0(2)$ & $\begin{array}{c}-33.2(2) \\
109.2(2)\end{array}$ & $\begin{array}{l}-48.1(2) \\
172.3(2)\end{array}$ & & & \\
\hline $\begin{array}{c}(R)-1 \\
(\mathrm{~mol} \mathrm{~B})\end{array}$ & $60.2(2)$ & $\begin{array}{c}47.0(2) \\
-172.0(2)\end{array}$ & $\begin{array}{c}33.8(2) \\
-108.3(2)\end{array}$ & & & \\
\hline$( \pm)-1$ & $-55.2(5)$ & $\begin{array}{c}-49.8(5) \\
-175.2(5)\end{array}$ & $\begin{array}{l}-34.5(4) \\
111.3(5)\end{array}$ & & & \\
\hline$(R, R)-2$ & $\begin{array}{l}36.6(5) \\
36.7(5)\end{array}$ & $\begin{array}{c}38.6(4) \\
-98.9(5)\end{array}$ & $\begin{array}{c}49.0(4) \\
-109.2(4)\end{array}$ & $\begin{array}{c}-167.2(4) \\
106.2(6)\end{array}$ & $\begin{array}{c}52.0(4) \\
-170.4(4)\end{array}$ & \\
\hline $\begin{array}{c}(\text { meso })-2 \\
(\mathrm{~mol} \mathrm{~A})\end{array}$ & $\begin{array}{c}16.4(1) \\
-16.4(1)\end{array}$ & $\begin{array}{c}57.4(1) \\
-163.1(8)\end{array}$ & $\begin{array}{c}58.7(8) \\
165.4(2)\end{array}$ & $\begin{array}{l}-57.4(1) \\
163.1(8)\end{array}$ & $\begin{array}{c}-58.7(8) \\
-165.4(2)\end{array}$ & \\
\hline $\begin{array}{c}\text { (meso)-2 } \\
(\mathrm{mol} \mathrm{B})\end{array}$ & $\begin{array}{c}-19.9(1) \\
19.9(1)\end{array}$ & $\begin{array}{l}-45.7(8) \\
163.3(2)\end{array}$ & $\begin{array}{c}-56.1(1) \\
-178.1(1)\end{array}$ & $\begin{array}{c}\text { 56.1(1) } \\
178.1(1)\end{array}$ & $\begin{array}{c}45.7(8) \\
-163.3(2)\end{array}$ & \\
\hline$(R, R)-3$ & $\begin{array}{c}27.1(5) \\
1.1(4)\end{array}$ & $\begin{array}{c}39.4(5) \\
-116.5(5)\end{array}$ & $\begin{array}{c}58.4(5) \\
-164.2(5)\end{array}$ & $\begin{array}{l}45.5(4) \\
87.6(6)\end{array}$ & $\begin{array}{c}58.2(5) \\
-178.5(4)\end{array}$ & $\begin{array}{l}-24.3(4) \\
-24.8(5)\end{array}$ \\
\hline$(R, R / S, S)-3$ & $\begin{array}{l}-39.1(6) \\
-44.5(5)\end{array}$ & $\begin{array}{c}-52.9(6) \\
-158.9(5)\end{array}$ & $\begin{array}{c}-170.6(5) \\
165.2(5)\end{array}$ & $\begin{array}{c}54.2(6) \\
172.6(5)\end{array}$ & $\begin{array}{l}-178.6(5) \\
-162.5(7)\end{array}$ & $\begin{array}{c}-3.0(5) \\
-11.7(6)\end{array}$ \\
\hline
\end{tabular}

Supplementary Materials: The following are available online at http://www.mdpi.com/2073-4352/9/12/606/s1. CCDC 1961489-1961494 contains the supplementary crystallographic data for this paper. These data can be obtained free of charge from The Cambridge Crystallographic Data Centre.

Author Contributions: O.K. and K.M. prepared the manuscript with contributions of all other co-authors, R.Z., K.N., D.S., E.B. carried out synthetic work and crystal growth, Z.Y. and K.I. carried out X-ray single crystal diffraction studies, O.S. and V.A. are responsible for project administration.

Funding: This work was supported by the grant of the Russian Foundation for Basic Research, grant No 18-43-160018.

Acknowledgments: The authors gratefully acknowledge the Spectral-Analytical Center "CSF-SAC FRC KSC RAS" for providing necessary facilities to carry out this work. K. Ivshin is thankful to the Russian Government Program of Competitive Growth of Kazan Federal University.

Conflicts of Interest: The authors declare no conflict of interest.

\section{References}

1. Berthod, A. Chiral recognition mechanism. Anal. Chem. 2006, 78, 2093-2099. [CrossRef] [PubMed]

2. Bissantz, C.; Kuhn, B.; Stahl, M. A medicinal chemist's guide to molecular interactions. J. Med. Chem. 2010, 53, 5061-5084. [CrossRef] [PubMed]

3. Jędrzejewska, H.; Szumna, A. Making a right or left choice: Chiral self-sorting as a tool for the formation of discrete complex structures. Chem. Rev. 2017, 117, 4863-4899. [CrossRef] [PubMed]

4. Xing, P.; Zhao, Y. Controlling supramolecular chirality in multicomponent self-assembled systems. Acc. Chem. Res. 2018, 51, 2324-2334. [CrossRef]

5. Song, L.; Shemchuk, O.; Robeyns, K.; Braga, D.; Grepioni, F.; Leyssens, T. Ionic cocrystals of etiracetam and levetiracetam: The importance of chirality for ionic cocrystals. Cryst. Growth Des. 2019, 19, 2446-2454. [CrossRef]

6. Guijarro, A.; Yus, M. The Origin of Chirality in the Molecules of Life: A Revision from Awareness to the Current Theories and Perspectives of this Unsolved Problem, 1st ed.; Royal Society of Chemistry: Cambridge, UK, 2009; p. 160.

7. Tsang, M.Y.; Di Salvo, F.; Teixidor, F.; Viñas, C.; Planas, J.G.; Choquesillo-Lazarte, D.; Vanthuyne, N. Is molecular chirality connected to supramolecular chirality? The particular case of chiral 2-pyridyl alcohols. Cryst. Growth Des. 2015, 15, 935-945. [CrossRef]

8. Scriba, G.K.E. Recognition mechanisms of chiral selectors: An overview. In Chiral Separations. Methods and Protocols; Scriba, G.K.E., Ed.; Humana Press: Totowa, NY, USA, 2019; Volume 1985, pp. 1-33. 
9. Sørensen, H.O.; Larsen, S. Hydrogen bonding in enantiomeric versus racemic mono-carboxylic acids; a case study of 2-phenoxypropionic acid. Acta Crystallogr. B 2003, 59, 132-140. [CrossRef]

10. Gavezzotti, A.; Lo Presti, L. Theoretical study of chiral carboxylic acids. Structural and energetic aspects of crystalline and liquid states. Cryst. Growth Des. 2015, 15, 3792-3803. [CrossRef]

11. Metlushka, K.E.; Sadkova, D.N.; Shaimardanova, L.N.; Nikitina, K.A.; Ivshin, K.A.; Islamov, D.R.; Kataeva, O.N.; Alfonsov, A.V.; Kataev, V.E.; Voloshina, A.D.; et al. First coordination polymers on the bases of chiral thiophosphorylated thioureas. Inorg. Chem. Commun. 2016, 66, 11-14. [CrossRef]

12. Kataeva, O.N.; Metlushka, K.E.; Yamaleeva, Z.R.; Ivshin, K.A.; Kiiamov, A.G.; Lodochnikova, O.A.; Nikitina, K.A.; Sadkova, D.N.; Punegova, L.N.; Voloshina, A.D.; et al. Co-ligand induced chiral recognition of $N$-thiophosphorylated thioureas in crystalline Ni(II) complexes. Cryst. Growth Des. 2019, 19, 4044-4056. [CrossRef]

13. Bruker. APEX3 Crystallography Software Suite; Bruker AXS Inc.: Madison, WI, USA, 2016.

14. Bruker. SAINT. Crystallography Software Suite; Bruker AXS Inc.: Madison, WI, USA, 2016.

15. Sheldrick, G.M. A Short history of SHELX. Acta Crystallogr. A 2008, 64, 112-122. [CrossRef]

16. Krause, L.; Herbst-Irmer, R.; Sheldrick, G.M.; Stalke, D. Comparison of silver and molybdenum microfocus X-ray sources for single-crystal structure determination. J. Appl. Crystallogr. 2015, 48, 3-10. [CrossRef]

17. Mitoraj, M.P.; Babashkina, M.G.; Robeyns, K.; Sagan, F.; Szczepanik, D.W.; Seredina, Y.V.; Garcia, Y.; Safin, D.A. Chameleon-like nature of anagostic interactions and its impact on metalloaromaticity in square-planar nickel complexes. Organometallics 2019, 38, 1973-1981. [CrossRef]

18. Safin, D.A.; Babashkina, M.G.; Robeyns, K.; Mitoraj, M.P.; Kubisiak, P.; Garcia, Y. Influence of the homopolar dihydrogen bonding $\mathrm{C}-\mathrm{H} \cdots \mathrm{H}-\mathrm{C}$ on coordination geometry: Experimental and theoretical studies. Chem. Eur. J. 2015, 21, 16679-16687. [CrossRef]

19. Safin, D.A.; Babashkina, M.G.; Bolte, M.; Mitoraj, M.P.; Klein, A. Complexing cation influences distortion of the ligand in the structure of $\left[\mathrm{M}\left\{2-\mathrm{MeO}(\mathrm{O}) \mathrm{CC}_{6} \mathrm{H}_{4} \mathrm{NHC}(\mathrm{S}) \mathrm{NP}(\mathrm{S})(\mathrm{O} i \mathrm{Pr})_{2}\right\}_{2}\right]\left(\mathrm{M}=\mathrm{Zn}^{\mathrm{II}}, \mathrm{Cd}^{\mathrm{II}}\right)$ complexes: A driving force for the intermolecular aggregation. Dalton Trans. 2015, 44, 14101-14109. [CrossRef]

20. Babashkina, M.G.; Safin, D.A.; Srebro, M.; Kubisiak, P.; Mitoraj, M.P.; Bolte, M.; Garcia, Y. Crucial influence of the intramolecular hydrogen bond on the coordination mode of $\mathrm{RC}(\mathrm{S}) \mathrm{NHP}(\mathrm{S})(\mathrm{O} i \mathrm{Pr})_{2}$ in homoleptic complexes with $\mathrm{Ni}^{\mathrm{II}}$. Eur. J. Inorg. Chem. 2013, 2013, 545-555. [CrossRef]

21. Babashkina, M.G.; Safin, D.A.; Srebro, M.; Kubisiak, P.; Mitoraj, M.P.; Bolte, M.; Garcia, Y. Influence of $\mathrm{CH}_{2} \mathrm{Cl}_{2}$ for the structure stabilization of the $\mathrm{Ni}^{\mathrm{II}}$ complex $\left[\mathrm{Ni}\left\{6-\mathrm{MeO}(\mathrm{O}) \mathrm{CC}_{6} \mathrm{H}_{4} \mathrm{NHC}(\mathrm{S}) \mathrm{NP}(\mathrm{S})(\mathrm{O} i \mathrm{Pr})_{2}-1,5-\mathrm{S}, \mathrm{S}^{\prime}\right\}_{2}\right] \cdot \mathrm{CH}_{2} \mathrm{Cl}_{2}$. CrystEngComm 2012, 14, $370-373$. [CrossRef]

22. Babashkina, M.G.; Safin, D.A.; Robeyns, K.; Garcia, Y. Complexation properties of the crown ether-containing $\mathrm{N}$-thiophosphorylated thiourea towards NiII. Dalton Trans. 2012, 41, 1451-1453. [CrossRef]

23. Safin, D.A.; Babashkina, M.G.; Bolte, M.; Klein, A. Versatile structures and photophysical properties of poly- and mononuclear $\mathrm{Cu}^{\mathrm{I}}$ complexes with $\mathrm{N}$-thiophosphorylated thioureas $\mathrm{RNHC}(\mathrm{S}) \mathrm{NHP}(\mathrm{S})(\mathrm{O} i \mathrm{Pr})_{2}$ and phosphanes. CrystEngComm 2011, 13, 568-576. [CrossRef]

24. Babashkina, M.G.; Safin, D.A.; Bolte, M.; Srebro, M.; Mitoraj, M.; Uthe, A.; Klein, A.; Köckerling, M. Intramolecular hydrogen bonding controls $1,3-N, S$ vs. 1,5- $S, S^{\prime}$-coordination in $\mathrm{Ni}^{\mathrm{II}}$ complexes of $\mathrm{N}$-thiophosphorylated thioureas RNHC(S)NHP(S)(OiPr) 2 . Dalton Trans. 2011, 40, 3142-3153. [CrossRef]

25. Safin, D.A.; Babashkina, M.G.; Bolte, M.; Klein, A. Synthesis and characterization of $\left[\mathrm{H}_{2} \mathrm{NC}(\mathrm{S}) \mathrm{NP}(\mathrm{S})(\mathrm{O} i \mathrm{Pr})_{2}\right]^{-}$ complexes of $\mathrm{Co}(\mathrm{II}), \mathrm{Ni}(\mathrm{II}), \mathrm{Zn}(\mathrm{II})$ and Cd(II). Inorg. Chim. Acta 2011, 365, 32-37. [CrossRef]

26. Metlushka, K.E.; Sadkova, D.N.; Nikitina, K.A.; Lodochnikova, O.A.; Kataeva, O.N.; Alfonsov, V.A. Ni(II) complex of bisthiophosphorylated thiourea prepared from the Betti base. Russ. J. Gen. Chem. 2017, 87, 2130-2132. [CrossRef]

27. Safin, D.A.; Babashkina, M.G.; Mitoraj, M.P.; Kubisiak, P.; Robeyns, K.; Bolte, M.; Garcia, Y. An intermolecular pyrene excimer in the pyrene-labeled $N$-thiophosphorylated thiourea and its nickel(II) complex. Inorg. Chem. Front. 2016, 3, 1419-1431. [CrossRef]

(C) 2019 by the authors. Licensee MDPI, Basel, Switzerland. This article is an open access article distributed under the terms and conditions of the Creative Commons Attribution (CC BY) license (http://creativecommons.org/licenses/by/4.0/). 